\title{
Development of the mathematical model a single stage pulse hydraulic drive
}

\author{
Dmytro Mishchuk \\ Kyiv National University of Construction and Architecture \\ Povitroflotsky avenue 31, Kyiv, Ukraine, 03037 \\ mischuk84@gmail.com, orcid.org/0000-0002-8263-9400
}

Received on 05.11.2018, accepted after revision on 10.12.2018

DOI: $10.31493 /$ tit1812.0202

\begin{abstract}
The hydraulic drive is used in most structures of construction and road equipment. Hydrostatic volumetric drive allows the working bodies of construction machines to perceive heavy loads with a high rate of energy transfer. This gives of advantages not available on electric machines.

The control of the hydraulic drive can be proportional and discrete. Proportional control is more precise control in comparison with discrete, however, more energy consuming. The discrete switching mode of the hydraulic drive can be performed using a high-speed valve, which is widely used for pilot valves because of their advantages in terms of simplicity of digital control, low power losses and insensitivity to contamination. However, to control such hydraulic valves, it is necessary to clearly understand and represent the principal features of the operation of a pulsed hydraulic system, to know the optimal values of the control system settings and transient parameters, to understand the relationships between the input control signals and the outgoing kinematic parameters.

In this study, we developed a mathematical model that allows us to investigate the dynamics of high-velocity fluid flow switching valve for controlling the hydraulic power consumer.

Mathematical modeling is proposed to be carried out over a typical cell of a hydraulic system consisting of a linear hydraulic cylinder, which is a consumer of hydraulic energy and a high-speed control spool valve. The actuating spool valve consists of a body inside which the valve moves, driven by a solenoid, at the input contacts of which a variable magnetic flux is generated, forming a variable magnetic force. Inside the body of the
\end{abstract}

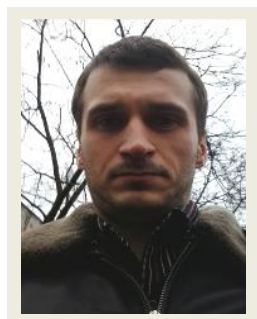

\section{Dmytro Mishchuk}

Associate Professor of the Construction Machines Department, PhD, Ass. Prof.

high-speed valve, the return spring of the spool is also installed, which is used to balance it.

For the input of the valve control electric solenoid is energized variable frequency. By adjusting the fill factor of the control signal by pulse-width modulation, it is possible to change the magnitude of the spool force, thereby performing its programmatic movement.

Thus will be regulated distributor spool slits overlap, thereby passing a continuous flow and fluid pressure through a distributor.

Keywords: high-speed hydraulic valve, control performance, mathematical modeling.

\section{INTRODUCTION}

The current need to carry out regulated software transfer of the working equipment of machines by hydraulic actuating devices poses a challenging practical task for researchers and engineers [1] associated with the development of new and improvement of existing designs of hydraulic control devices $[2,3]$.

The use of hydraulic systems with high values of working pressures (about $32 \mathrm{MPa}, 64$ $\mathrm{MPa}$ ) significantly complicates the processes 
of controlling the working equipment of machines, due to the effect on the installation and components of the machine of high hydrostatic forces $[4,5]$. This is especially necessary for the construction of construction equipment, such as excavators. In article [6], a new design of a digging machine is considered, the hydraulic system of which requires new modern hydraulic discrete control systems.

Thus, the problem of modeling of the hydraulic actuator for the purpose of investigation of dynamic parameters is an actual practical work.

\section{PURPOSE OF WORK}

Using traditional control valves with discrete control to regulate changes in the direction of flow working fluid in the hydraulic drive mechanisms of construction machines, if it is necessary to perform control according to the specified laws of movement the working body, an overflow valve and control flow of the working fluid are additionally installed.

Through the fact that that the construction machine is operating under various load conditions, it is not possible to fine-tune the parameters of the control system, which leads to a change in the working conditions of the working body of the machine. Ambiguity and volatility of the machine does not affect the efficiency of hydraulic manipulators, building robots and lifting jib cranes [7], which deteriorates accuracy and smoothness of stroke is significantly reduced [8] is very much such.

Proportional hydraulic control allows the construction machine control system been adapted to external conditions. The technical advantages of proportional control are primarily in controlled switching transitions, smooth control of specified values and reduction in the number of hydraulic devices for defining control tasks, since most control tasks are solved at the program level by programming the proportional valve electronic control unit [9]. The development and introduction of proportional valves in construction machinery are engaged in such foreign companies like Bosch Rexroth, Brevini Hydraulics, Hydrocontrol, Sauer Danfoss, the basic knowledge which is based on the investigations of proportional control Follingera A. [10] A. Schmitt, Krettsa D. Scholz D. [11] and others.

Although the proportional hydraulic drive has an advantage over the discrete one, under the same conditions it requires a more complex control system. Such a control system will have to monitor the position of the control spool and perform a change in its position in accordance with a given program. In high pressure hydraulic systems, the efficiency of proportional control is reduced, since it requires a significant amount of energy to implement such control.

One of the ways to reduce energy consumption in the control system of hydraulic actuators is the use of discrete control valves with high-speed switching of the control element based on pulse-width control [11]. High-speed valves are widely used in hydraulic and pneumatic systems due to their advantages, such as compact design, low cost, easy digital control, low power loss and insensitivity to contamination. The switching frequency and the nominal flow of the working fluid are the two main and important indicators for evaluating the effectiveness of hydraulic high-speed valves.

Thus it serves to investigate qualitatively workflow discrete hydraulic actuator with a pulse-controlled parameters to identify its rational use.

\section{TASKS OF RESEARCH}

The purpose of this work is to develop a mathematical model of control of a volumetric hydraulic drive with a high-speed control valve switching. Valve control should be implemented through an electrical system with pulse-width modulated control signal.

\section{METHODS OF THE STUDY}

The D'Alember approach is used as the main method for describing the equations of motion of the executive body of the hydraulic drive and the working element of the spool. Electrical transients in an electromagnetic converter is written based on the Maxfel equations and Ohm's law. The dynamics of the hy- 
draulic system is described by the equations of continuity of fluid flow, the equations of state and the equations of energy.

\section{RESULTS OF RESEARCH}

To construct a mathematical model of the high-speed control of a linear hydraulic cylinder, considered single-control valve with magnetic actuator, the circuit is shown on Fig. 1.

The structure of the distributor includes a housing 1 , a spool 2 , a solenoid electromagnet 3 and a spring 4 . When applying to the electromagnet 3 voltage with different on/off frequency, various power loads are formed on the movable slide 2 .

The dynamic transient of a high-speed electric solenoid can be written as [12, 13]:

$$
U_{e m}=R_{e m} I_{e m}+L_{e m} \frac{d I_{e m}}{d t}+\psi \frac{d x_{z}}{d t},
$$

where

$U_{e m}$ - control voltage at the input of the solenoid, which is performed by moving the valve spool,

$$
R_{e m} \text { - active resistance of the solenoid wind- }
$$

ing,

$L_{e m}$ - the inductance of the winding of the solenoid electromagnet,

$I_{e m}$ - current in the control coil of the solenoid, $\psi$ - coefficient of anti-driving force,

$x_{z}$ - movement of the distributor spool, which for the solenoid electromagnet is its anchor.

The plunger of the spool valve distributor under the action of electromagnetic force will begin to move in the direction of the force action vector, and braking forces will arise from the elastic link, which, together with the dissipative forces, will resist displacement. The dynamic equation of motion of this process will be described as follows:

$$
m_{z} \frac{d^{2} x_{z}}{d t^{2}}=F_{m}-F_{c}-F_{b}-F_{R},
$$

where

$m_{z}-$ it is mass of the plunger,

$F_{m}-$ it's driving electromagnetic force,

$F_{c}=c_{n p_{-} z} x_{z}-$ it's spring resistance force,

$F_{b}=b_{z} \frac{d x_{z}}{d t}$ - the force of viscous resistance from the friction of the plunger along the

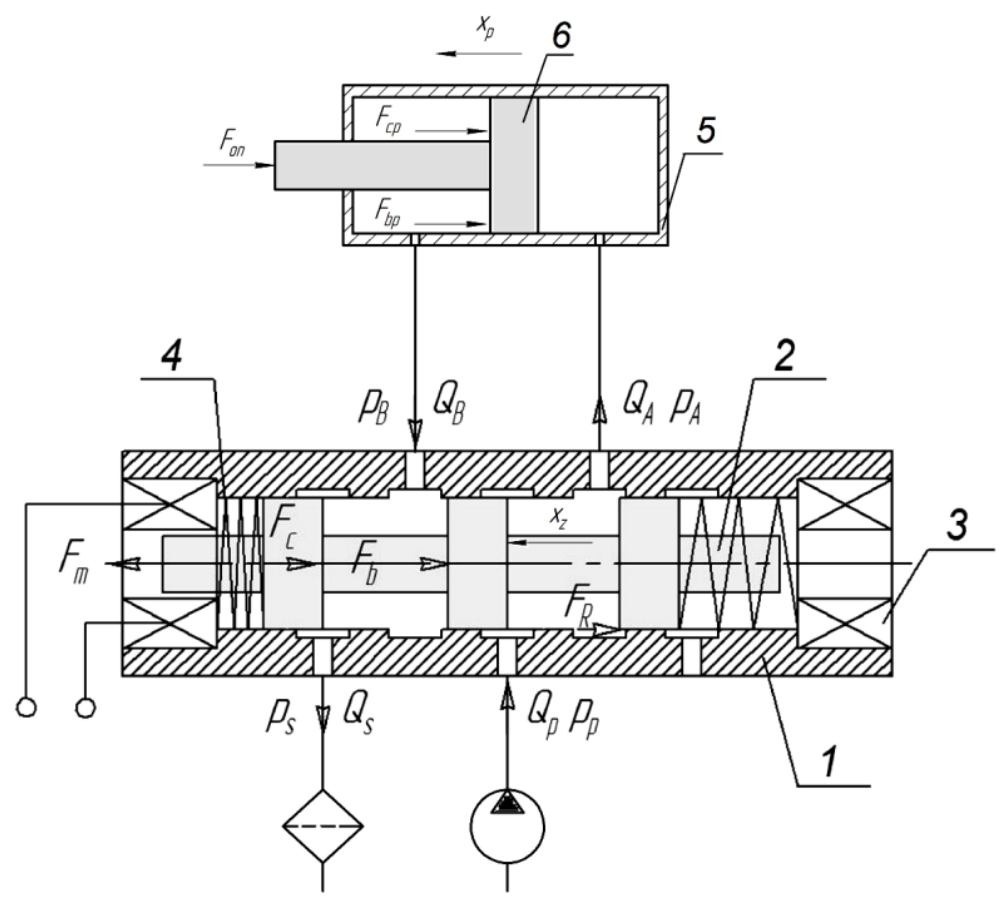

Fig.1. The design scheme of the distributor with an electromagnetic drive: 1 - case; 2 - spool; 3 - electromagnet; 4 - spring; 5 - hydraulic cylinder; 6 - movable piston 
sleeve of the spool body,

$F_{R}$ - hydrodynamic force acting on the gold from the working fluid,

$c_{n p_{-} z}-$ spring stiffness,

$b_{\mathrm{z}}-$ it's the coefficient of viscous friction in the gap between the plunger and the sleeve of the grain trap.

On the basis of Maxwell's electromagnetic theory, the magnetic force, which the highspeed solenoid creates, can be defined as follows [14]:

$$
F_{m}=\frac{\lambda \Phi^{2}}{2 \mu \pi r^{2}},
$$

where

$\mu-$ is the magnetic permeability of the air,

$r-$ is the plunger radius,

$\lambda$ - the efficiency of the magnetic field of the solenoid (from 0 to 1 ),

$\Phi$ - is the total magnetic flux, the average value of which for a solenoid with the number of turns $\mathrm{N}$ is determined by the following expression

$$
\Phi=\frac{I_{e m} N}{R_{e m}} .
$$

The nature of the pressure change in the working hydro lines of the hydraulic distributor, which provides the supply of hydraulic energy to consumers, is determined from the flow continuity equations taking into account the compression of the working fluid [15]:

$$
\begin{aligned}
& \frac{d p_{A}}{d t}=\frac{E_{3 \beta_{-} A}}{V_{1}}\left(Q_{A}-q_{1}\right), \\
& \frac{d p_{B}}{d t}=\frac{E_{3 \varepsilon_{-} B}}{V_{2}}\left(-Q_{B}+q_{2}\right),
\end{aligned}
$$

where

$Q_{A}$ and $Q_{B}$ - fluid flow in the pressure and discharge lines of consumers connected to the appropriate distributor channels,

$E_{3 \varepsilon_{-} A}$ and $E_{3 \varepsilon_{-} B}$ - the module of the bulk elasticity of the working fluid in the corresponding cavities of the consumer connected to the distributor,

$V_{1}$ and $V_{2}-$ it's the initial volumes of the working fluid in the injection and discharge cavities of the consumer, taking into account the volumes of fluid in the adjacent pipelines, $q_{1}=\pi r^{2} \frac{d x_{z}}{d t}$ and $q_{2}=\pi r^{2} \frac{d x_{z}}{d t}-$ the change in the flow rate of the working fluid in the discharge and drain of the consumer.

The flow of the working fluid in the pressure and drain line of the consumer is determined by its costs through the cylindrical slots of the spool valve:

$$
\begin{gathered}
Q_{A}=\eta_{A} \pi d_{3} x_{z} \sqrt{\frac{2\left|p_{p}-p_{A}\right|}{\rho}} \operatorname{sign}\left(p_{p}-p_{A}\right),( \\
Q_{B}=\eta_{B} \pi d_{3} x_{z} \sqrt{\frac{2\left|p_{B}-p_{s}\right|}{\rho}} \operatorname{sign}\left(p_{B}-p_{s}\right),
\end{gathered}
$$

where

$\eta_{A}$ and $\eta_{B}$ - the coefficients of the flow rate of the working fluid through the throttle channels of the distributor,

$\rho-$ is the density of the working fluid,

$p_{p}$ - working pressure of the hydraulic pump,

$p_{s}$ - pressure in the drain line,

$d_{3}$ - the diameter of the plunger spool.

The acceleration of the movement of the hydraulic cylinder rod will be determined from the equation:

$$
\frac{d^{2} x_{p}}{d t^{2}}=\frac{1}{m_{\Sigma}}\left(p_{A} S_{A}-p_{B} S_{B}-F_{o n}-F_{c p}-F_{b p}\right),(9)
$$

where

$m_{\Sigma}-$ the mass of the moving parts of the rod of the hydraulic cylinder,

$S_{A}=\pi \frac{D_{A}^{2}}{4}$ and $S_{B}=\pi \frac{\left(D_{A}^{2}-D_{B}^{2}\right)}{4}$ - respec-

tively, the area of the piston and rod planes of the hydraulic cylinder,

$D_{\mathrm{A}}$ - the diameter of the piston,

$D_{\mathrm{B}}$ - the stem diameter,

$F_{o n}-$ it's external resistance force, 
$F_{c p}=c_{n p_{-} p} x_{p}-$ the reaction from the compression of the walls of the cylinder, pipelines and liquids,

$F_{b p}=b_{p} \frac{d x_{p}}{d t}-$ it's the additional effort that is spent on damping the fluid in the drain line, $\frac{d x_{p}}{d t}=\int \frac{d^{2} x_{p}}{d t^{2}}-$ it's piston speeds.

The obtained equations of the mathematical model are proposed to be investigated using numerical modeling with the recommended iteration step of more than 1000 steps.

The algorithm for calculating the proposed mathematical model is presented on Fig. 2.

At the initial stage of calculations, it is proposed to determine and enter the technical parameters of the hydraulic drive, such as cylinder, stem and spool diameters, pressure at the hydraulic pump outlet and in the drain line, average stiffness and damping coefficients, external force resistance, solenoid winding resistance and its inductance. It is necessary to determine the initial parameters of the system and set their values after that. Further, according to the algorithm, it is necessary to form a cycle and determine by numerical calculations the parameters of the magnetic force needed to move the spool, its speed and displacement, acceleration, speed and displacement of the piston of the driving hydraulic cylinder.

In [16], the efficiency of using a high-speed hydraulic switching valve, which is similar to what is investigated in this article, is shown. However, in this work, a pilot valve with a maximum pressure of $1,35 \mathrm{MPa}$ and a flow rate of $5 \mathrm{~L} / \mathrm{min}$ is considered, but for a controlled dynamic mode of operation of the machine, a single-stage valve is quite suitable.

\section{FINDINGS}

As result of the study, a mathematical model of a high-speed hydraulic distributor was analyzed and constructed, which should then be solved using numerical mathematical methods.

In the process of the work done, it became clear that the problem of mathematical modeling of volumetric hydraulic drives is a difficult technical problem, the solution of which is engaged in a number of scientific schools.

In the preliminary calculations, it became known that in the future to build an effective system of discrete hydraulic control, it is necessary to develop a two-stage control system and determine its dynamic characteristics.

The management concept it is proposed to use the proposed algorithm in the article [11].

\section{REFERENCES}

1. Sorin Ax.A., Scheaua F.D., 2015. Introduction to Industrial Hydraulics. Introducere în hidraulica industrială. Galati, Galati University Press, ISBN 978-606-696-032-8.

2. Pelevin L.Je., Mishchuk D.A., Rashkivskyj V.P., Gorbatjuk Je.V., Arzhajev G.O., Krasnikov V.F., 2015. Hydraulics, Hydraulic and hydropneumatics: Textbook, KNUCA Publ., Kyiv, 340.

3. Florian M., Rudolf S., 2016. Development and experimental results of a small fast switching valve derived from fuel injection technology. In: Proceedings of the eighth work-shop on digital fluid power, Tampere, Finland, Vol.24-25, 9-26.

4. Scheaua F.D., 2018. Theoretical aspects regarding the Pressure Safety Valves Operation within a Hydraulic Circuit. Hidraulica, Iss.1, 65-70.

5. Scheaua F.D., 2016. Functional description of a hydr aulic throttle valve operating inside a hydraulic circuit. Hidraulica. Magazine of Hydraulics, Pneumatics, Tribology, Ecology, Sensorics, Mechatronics, No.1, 47-50.

6. Sukach M., 2017. Modernization of powershovel by a two sectional turning arrow. Pidvodni tehnologii, No.7, 28-33 (in Ukrainian).

7. Lovejkin V.S., Mishchuk D.A., 2009. Overview of the basic designs of the hydraulic drive of cranes-manipulators on vehicles. Girnychi, budivelni, dorozhni ta melioratyvni mashyny, No.74, 20-27.

8. Lovejkin V.S., Mishchuk D.A., 2013. Optimization of the mode of changing the departure of the manipulator with a hydraulic drive: Monograph, CP «KOMPRINT», 206 (in Ukrainian).

9. Mishchuk D.A., 2014. Features of the implementation of proportional hydraulic control. International Scientific and Practical Conference Modern Information and Innovative Technologies in Transport (MINTT-2014), 27-29 may, Kherson, Kherson Maritime University. 


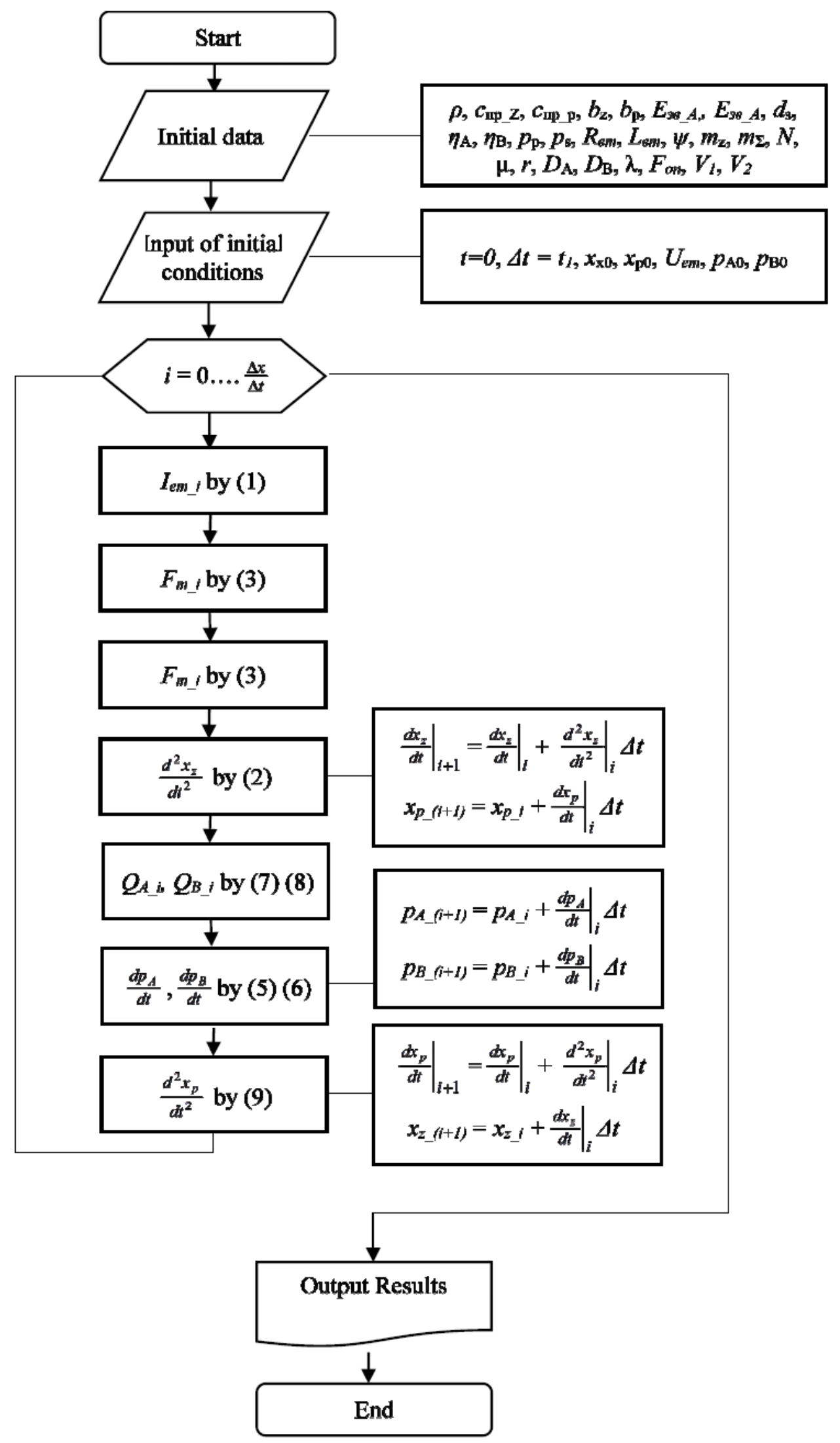

Fig.2. The algorithm for calculating hydraulic drive 
10. Sholc D., 2002. Proportional hydraulics. Basic course TR 701, Kyiv, DP Festo, 124.

11. Zhong Q., Zhang B., Yang Hua-Yong, JiEnMa, Fung Rong-Fong, 2017. Performance analysis of a high-speed on/off valve based on an intelligent pulse-width modulation control. Advances in Mechanical Engineering, Vol.9 (11),1-11. doi.org/10.1177/1687814017733247.

12. Pellikka M, Ahola V, Soederlund L, et al., 2011. Genetic optimization of a fast solenoid actuator for a digital hydraulic valve. Int J Fluid Power, Vol.12, 49-56.

13. Zhao J., Wang M., Wang Z., et al., 2017. Different boost voltage effects on the dynamic response and energy losses of high-speed solenoid valves. Appl Therm Eng, Vol.123, 1494-1503.

14. Goodfriend M., Sewell J., Jones C., 1990. Application of a magnetostrictive alloy, terfenol-D to direct control of hydraulic valves. SAE technical paper 901581.

15. Mischuk D., 2016. Hydraulic cylinder of the volumetric hydraulic drive research of the dynamic model. Girnychi, budivelni, dorozhni ta melioratyvni mashyny, No.87, 74-81 (in Ukrainian).

16. Wang Sh., Zhang B., Zhong Q., Yang Hu., 2017. Study on control performance of pilot high-speed switching valve. Advances in Mechanical Engineering, 9(7), 1-8.

\section{Разработка математической модели одно- каскадного импульсного гидропривода}

\section{Дмитрий Мищук}

Аннотация. Гидравлический привод используется в большинстве конструкций строительной и дорожной техники. Гидростатиче ский объемный привод позволяет рабочим органам строительных машин воспринимать тяжелые нагрузки с высокой скоростью передачи энергии. Все это дает преимущества по сравнению с аналогичными соизмеримыми электрическими приводами машин.

Управление гидравлическим приводом может быть пропорциональным и дискретным. Пропорциональное управление является более точным управлением в сравнении с дискретным, однако и более энергетически затратным. Дискретный режим переключения гидравлического привода может быть выполнен с использованием высокоскоростного клапана, который широко используется для пилотных клапанов из-за их преимуществ с точки зрения простоты цифрового управления, низких потерь мощно- сти и нечувствительности к загрязнению рабочей среды. Однако для управления такими гидравлическими клапанами необходимо четко понимать и представлять принципиальные особенности работы импульсной гидравлической системы, знать оптимальные значения настроек системы управления и параметры переходного процесса, понимать взаимосвязи между входными управляющими сигналами и исходящими кинематическими параметрами. В представленной работе разработано математическую модель, которая позволяет исследовать динамику быстродействующего клапана переключения потока жидкости для управления потребителем гидравлической энергии.

Математическое моделирование предлагается провести над типовой ячейкой гидравлической системы, состоящей из линейного гидравлического цилиндра, который является потребителем гидравлической энергии и высокоскоростного управляющего золотникового клапана. Приводной золотниковый клапан состоит из корпуса внутри которого перемещается золотник с приводом от соленоида, на входных контактах которого генерируется переменный магнитный поток, формирующий переменную магнитную силу. Внутри корпуса быстроходного клапана также установлено возвратную пружину золотника, которая используется для его уравновешивания.

Для управления клапаном на вход электрического соленоида подается напряжение переменной частоты. Регулируя коэффициент заполнения сигнала управления широтноимпульсной модуляцией, можно изменять величину тягового усилия золотника, выполняя тем самым его программное перемещение. Таким образом будет происходить регулированное перекрытие щелей золотникового распределителя, пропуская тем самым непрерывный поток и давление жидкости через распределитель.

Ключевые слова: быстродействующий гидравлический клапан, показатели управления, математическое моделирование. 